\title{
KARAKTERSITIK KHAMIR AMILOLITIK DARI BERBAGAI MACAM BUAH
}

\author{
Oleh:
}

\author{
Jefri Nur Hidayat, Siswanto dan Esti Utarti
}

Jurusan Biologi, Fakultas Matematika dan Ilmu Pengetahuan Alam, Universitas Jember.

\begin{abstract}
ABSTRAK
Enam puluh juta ton amilum per tahun di Indonesia memiliki nilai jual yang rendah berdasarkan nilai ekonomi skala internasional. Peningkatan pemanfaatan amilum dapat dilakukan dengan menghidrolisis amilum menjadi glukosa secara enzimatik oleh mikrob amilolitik. Yeast amilolitik memiliki pertumbuhan yang lebih cepat, lebih efektif memecah amilum dari kapang dan dapat digunakan sebagai protein sel tunggal. Penelitian ini bertujuan untuk mendapatkan isolat yeast amilolitik yang berasal dari buah sukun, buah pisang, buah mangga dan buah durian. Hasil isolasi didapatkan 11 isolat yeast. Uji semikuantitatif dengan media SSA terhadap 11 isolat yeast, terdapat 5 isolat yang bersifat amilolitik yaitu isolat SiJi-P3, SiJi-P5, SiJi-S1, SiJi-S2, dan SiJi-M2. Isolat SiJi-P3 dan SiJi-P5 yang teridentifikasi sebagai Saccarhomyceteae mempunyai indek amilolitik terbesar.
\end{abstract}

Kata Kunci: Amilum, Yeast Amilolitik, Buah dan Glukosa

\section{PENDAHULUAN}

Indonesia merupakan penghasil amilum dengan jumlah 91,8 juta ton per tahunnya yang meliputi padi, ketela, jagung, pisang, dan ubi jalar (FAO dalam Nurachman, 2006). Meskipun produksi amilum berlimpah, tetapi sekitar 67,8 juta ton amilum per tahun memiliki nilai jual yang rendah berdasarkan nilai ekonomi skala internasional (Nurachman, 2006). Salah satu usaha untuk meningkatkan nilai jual amilum tersebut yaitu dengan mengubah amilum secara enzimatik menjadi glukosa (Winarno, 1995).

Proses pemecahan amilum menjadi glukosa secara enzimatik, melibatkan kelompok amilase (Schlegel dan Schmidt, 1994). Saat ini amilase menempati $30 \%$ total produksi enzim dunia dan permintaan pasar dunia sekitar 336 juta US\$ per tahun (The Freedonia Group dalam Natalia, 2006).

Amilase dapat diperoleh dari tanaman, hewan dan mikroorganisme. Mikroorganisme yang dapat menghasilkan amilase, misalnya bakteri, kapang dan yeast (Madigan et al., 1997). Keuntungan penggunaan yeast amilolitik adalah pertumbuhan yang relatif cepat (Fardiaz, 1989) dan lebih efektif memecah amilum dari kapang (Steward dan Russell, 1987). Yeast amilolitik juga dapat digunakan sebagai protein sel tunggal dengan menggunakan bahan yang mengandung amilum (Lemmel et al, 1990). Beberapa yeast amilolitik yang telah berhasil diisolasi dan telah dilakukan penelitian yaitu, Schwaniomyces occidentalis, Saccharomycopsis fibuliger, Saccharomyces diastiticus, Candida dan Pichia (De Mot dan Verachtret, 1992).

De Becze, 1955 menyatakan bahwa yeast dapat ditemukan ditempat yang kaya kandungan gula misalnya pada buah. Beberapa buah seperti sukun, pisang, mangga dan durian merupakan buah yang mempunyai kandungan karbohidrat seperti amilum dan gula sekitar $28 \%$. Kandungan karbohidrat yang relatif tinggi pada buah tersebut dapat menjadi salah satu habitat yeast amilolitik. Isolasi yeast pada buah yang mengandung karbohidrat diharapkan dapat memperoleh yeast yang mempunyai aktifitas amilolitik. 


\section{METODE}

Isolasi Yeast. Sampel diambil dari buah yang sudah busuk dengan menggunakan pinset steril pada bagian buah yang busuk. Sebanyak $100 \mu \mathrm{l}$ suspensi dari pengenceran $10^{-2}$ sampai $10^{-}$ 5 diinokulasikan secara taburan dalam cawan petri yang berisi media PDA dan diinkubasi pada suhu kamar selama 48 jam. Media PDA yang digunakan diberi antibiotik Streptomycin 100 ppm. Pemurnian dilakukan secara berulangulang sehingga didapatkan koloni-koloni yang terpisah.

Identifikasi Yeast. Identifikasi yeast meliputi pengamatan morfologi seperti bentuk sel, pseudomiselium dan bentuk spora. Pengamatan ini bertujuan untuk mendapatkan isolat yeast yang murni.

Pengamatan Bentuk Sel dan Pseudomiselium. Pengamatan bentuk sel dan pseudomiselium dilakukan dengan menginokulasikan biakan yeast ke dalam media PDB dan kemudian diinkubasi pada shaker dengan kecepatan $110 \mathrm{rpm}$ di suhu kamar selama 24 jam untuk mengamati bentuk sel. Inkubasi diteruskan hingga mencapai 168 jam untuk mengamati pseudomiselium (Talice dalam Henrici, 1950).

Pengamatan Bentuk Spora.

Pengamatan bentuk spora dilakukan dengan menginokulasikan biakan yeast pada media wortel tegak kemudian diinkubasi pada suhu kamar selama 2 minggu. Kemudian dilakukan pengecatan dengan cara difiksasi di atas bunsen. Setelah kering ditetesi dengan Anilin Crystal Violet, difiksasi selama 3 menit di atas bunsen, dicuci dengan akuades mengalir dan dilunturkan dengan alkohol asam. Bekas alkohol asam dicuci kembali dengan akuades mengalir, ditetesi dengan Safranin selama 10-15 detik, dicuci dengan air mengalir dan dikering anginkan. Kemudian diamati menggunakan mikroskop.

Uji Aktivitas Yeast Amilolitik Secara Semikuantitatif. Uji aktivitas amilolitik secara semikuantitatif dilakukan dengan menginokulasikan isolat yeast yang sudah diremajakan pada media SSA (Wichkerham et al, 1944) dan diinkubasi pada suhu kamar selama 24 jam. Aktivitas yeast amilolitik ditunjukkan dengan terbentuknya zona bening di sekitar koloni. Pengamatan zona bening dapat dilakukan dengan menambahkan larutan iodine pada permukaan media SSA (Schlegel dan Schmidt, 1994). Selanjutnya dipilih 2 jenis isolat yang mempunyai aktivitas amilolitik terbaik.

\section{HASIL DAN PEMBAHASAN \\ Karaktersitik Morfologi Khamir Hasil Isolasi dari Buah. \\ Hasil identifikasi berdasarkan} bentuk sel, isolasi dari buah sukun, pisang, mangga dan durian didapatkan 11 isolat yeast yang berbeda (Tabel 1).

Tabel 1. Karakteristik Isolat Yeast Hasil Isolasi Pada Berbagai Macam Buah

\begin{tabular}{|c|c|c|c|c|c|c|}
\hline \multirow[b]{2}{*}{ Isolat } & \multirow[b]{2}{*}{ Karakteristik Koloni } & \multicolumn{5}{|c|}{ Karakteristik Seluler } \\
\hline & & $\begin{array}{c}\text { Bentuk } \\
\text { sel }\end{array}$ & $\begin{array}{c}\text { Pseudo } \\
\text { miselium }\end{array}$ & $\begin{array}{l}\text { Jumlah } \\
\text { Tunas }\end{array}$ & Ascospora & $\begin{array}{c}\text { Jumlah } \\
\text { Spora }\end{array}$ \\
\hline SiJi-P3 & Warna putih, tepi rata & Bulat & Ada & $\begin{array}{c}\text { Multilater } \\
\text { al }\end{array}$ & Ada & $1-5$ \\
\hline SiJi-P5 & $\begin{array}{l}\text { Warna putih, tepi } \\
\text { bergelombang }\end{array}$ & Bulat & Ada & $\begin{array}{c}\text { Multilater } \\
\text { al }\end{array}$ & Ada & $1-5$ \\
\hline SiJi-S1 & $\begin{array}{l}\text { Warna putih, } \\
\text { permukaan licin }\end{array}$ & Bulat & $\mathrm{x}$ & $\mathrm{x}$ & $\mathrm{X}$ & $\mathrm{X}$ \\
\hline SiJi-S2 & $\begin{array}{l}\text { Warna putih, } \\
\text { permukaan kasap }\end{array}$ & Bulat & $\mathrm{x}$ & $\mathrm{x}$ & $\mathrm{x}$ & $\mathrm{x}$ \\
\hline SiJi-S3 & $\begin{array}{l}\text { Warna putih, } \\
\text { permukaan licin }\end{array}$ & Bulat & $\mathrm{x}$ & $\mathrm{x}$ & $\mathrm{x}$ & $\mathrm{x}$ \\
\hline
\end{tabular}




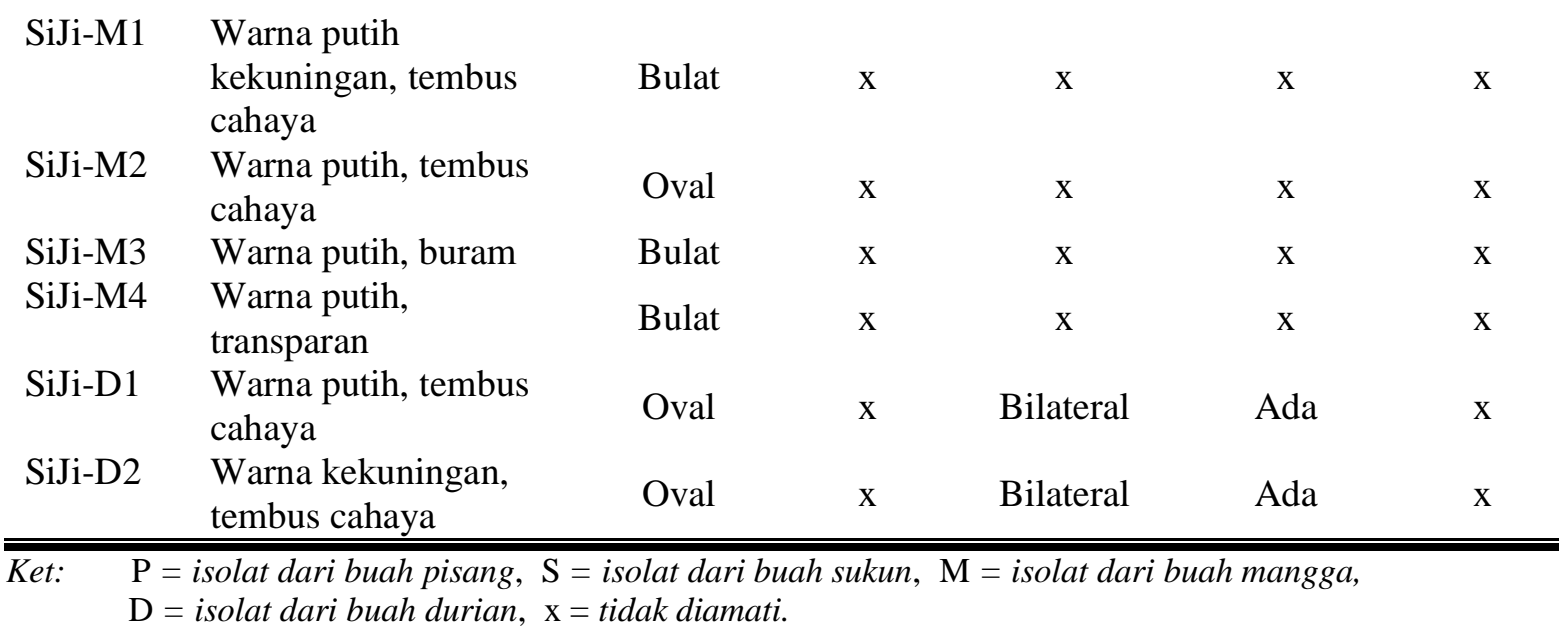

\section{Uji Semikuantitatif Pada Media SSA (Soluble Starch Broth)}

Hasil uji semikuantitatif dengan media SSA terhadap 11 isolat, terdapat 5 isolat yang bersifat amilolitik. Aktivitas amilolitik ditandai dengan terbentuknya zona bening disekitar koloni yeast. Terbentuknya zona bening pada media merupakan hasil hidrolisis soluble starch menjadi monosakarida dan disakarida oleh amilase ekstraseluler yeast. Amilase ekstraseluler merupakan enzim induktif yang akan dikeluarkan ke lingkungan jika terdapat oligosakarida dan polisakarida. De Mot dan Verachtret, (1992) menyatakan bahwa apabila di luar sel yeast terdapat oligosakarida dan polisakarida maka sel yeast yang mempunyai amilase ekstraseluler akan mengeluarkan enzim tersebut ke lingkungan untuk memecah oligosakarida dan polisakarida menjadi monosakarida sehingga dapat berdifusi ke dalam sel. Warna biru tua pada media menandakan adanya oligosakarida dan polisakarida yang belum terhidrolisis. Fessenden dan Fessenden, (1997) menyebutkan bahwa amilosa dalam konformasi helisal dapat menangkap iodium sehingga memberikan warna biru yang khas, sedangkan amilopektin akan berwarna ungu.

Isolat yeast amilolitik yang ditemukan yaitu isolat SiJi-P3, SiJi-P5, SiJi-S1, SiJi-S2, dan SiJi-M2. Sedangkan isolat SiJi-S3, SiJi-M1, SiJi-M3, SiJi-M4, SiJi-D1, dan SiJi-D2 tidak menunjukkan aktivitas amilolitik. Isolat yeast yang terpilih yaitu SiJi-P3 dan SiJi-P5 karena memiliki indeks aktifitas amilolitik yang lebih besar dari ke 4 isolat lainnya yaitu 2,31 dan 1,83 (Tabel 2).

Tabel 2. Indeks Aktivitas Amilolitik Isolat Yeast Pada Media Soluble Starch Broth Dengan Inkubasi $24 \mathrm{Jam}$.

\begin{tabular}{cc}
\hline \hline Isolat Yeast & Indeks Aktivitas Amilase \\
\hline SiJi-P3 & 2,31 \\
SiJi-P5 & 1,83 \\
SiJi-S1 & 1,78 \\
SiJi-S2 & 1,83 \\
SiJi-M2 & 1,55 \\
\hline \hline
\end{tabular}

\section{Identifikasi Isolat Yeast SiJi-P3 dan SiJi-P5}

Identifikasi isolat yeast terpilih menurut Henrici (1950) berdasarkan bentuk sel, jumlah pertunasan, ada tidaknya pseudomiselium dan jumlah spora. Isolat yeast SiJi-P3 dan SiJi-P5 termasuk suku Saccarhomyceteae. Isolat SiJi-P3 dan SiJi-P5 memiliki bentuk sel bulat, pertunasan mutlipolar, dapat 
membentuk pseudomiselium dan jumlah spora dalam askus berjumlah lebih dari 2 . Bentuk sel dan bentuk pseudomiselium dapat dilihat pada lampiran M. Kelompok ini mencakup sebagian besar dari yeast yang membentuk spora. Misalnya Saccharomyces, Pichia, Hansenula, Debaryomyces, dan Schwanniomyces.

\section{KESIMPULAN DAN SARAN Kesimpulan.}

1. Hasil isolasi dari buah sukun, pisang, mangga dan durian didapatkan 11 isolat yeast.

2. Isolat yeast SiJi-P3 dan SiJi-P5 termasuk suku Saccarhomyceteae. Isolat SiJi-P3 dan SiJi-P5 memiliki bentuk sel bulat, pertunasan mutlipolar, dapat membentuk pseudomiselium dan jumlah spora dalam askus berjumlah lebih dari 2

3. 5 isolat yeast amilolitik diantaranya SiJi-P3, SiJi-P5, SiJi-S1, SiJi-S2, dan SiJi-M2. Isolat SiJi-P3 dan SiJi-P5 merupakan isolat terpilih karena memiliki indeks aktifitas amilolitik tertinggi.

Saran. Yeast amilolitik isolat SiJi-P3 dan SiJi-P5 yang berhasil diisolasi belum diketahui jenisnya, temperatur dan $\mathrm{pH}$ optimumnya maka:

1. Perlu dilakukan identifikasi sampai tingkat species.

2. Perlu dilakukan penelitian terhadap temperatur dan $\mathrm{pH}$ optimum untuk pertumbuhan, produksi amilase dan aktifitas amilase.

3. Perlu dilakukan penelitian terhadap jenis amilase yang dimilikinya.

DAFTAR PUSTAKA

Ahmad, A. 2003. Purification and Characterization of

Amyloglucosidase Enzyme from Endomycopsis fibuligera. ISTEC JOURNAL [serial online] $\mathrm{Vol}$ $\mathrm{IV}: 47-55$.
Baum, Stuart. J., W. M. Bowen., dan S. N. Poulter. 1981. Laboratory Exercise in Organic and Biologycal Chemistry. Second Edition. New York: Mcmillan Publishing Co., Inc.

De Becze, G. I. 1955. A Microbilogical Process Report Yeasts: I. Morphology. Research Laboratories, Schenley Distillers, Inc., Lawrenceburg, Indiana.

De Mot, R., dan H. Verachtert. 1990. Yeast: Biotechnology and Biocatalysis. New York: Marcel Dekker, Inc.

Fardiaz, S. 1989. Mikrobiologi Pangan. Bogor: Direktorat Jenderal Pendidikan Tinggi Pusat Antar Universitas Pangan Dan Gizi. IPB.

Fessenden, R. J., and J. S. Fessenden. 1997. Dasar-Dasar Kimia Organik. Jilid II. Terjemahan Dra. Sukmariah Maun, Dra. Kamianti Anas, dan Dra. Tilda Sally. Jakarta Barat: Binarupa Aksara.

Henrici, A. T. 1950. The Yeasts: Genetics, Cytology, Variation, Classification and Identification. www.mmbr.asm.org

Lemmel, S. A., R. C. Heimsch., dan R. A. Korus. 1990. Kinetics of Growth and Amylase Production of Saccharomycopsis fibuligera on Potato Processing Wastewatert. Applied And Environmental Microbiology Journal, Vol. 39 No. 2.

Madigan, M.T., M. Martinko., and J. Parker. 1997. Brock Biology of Microorganisme. International Edition. New York. Prentice Hall Internatonal Inc.

Natalia, D. 2006. $\alpha$-Amilase Recombinan. www.fmipa.itb.ac.id/wp-content/ uploads/2006/09/dessy\%20fmipa \%202006.pdf. [26 Februari 2006].

Nurachman, Z. 2006. Enzim Pengubah Pati. www.fmipa.itb.ac.id/wpcontent/ uploads/2006/09/Enzim\%20pengu 
bah\%20pati.pdf. [26 Februari

2006]

Schlegel, H. G., dan K. Schmidt. 1994.

Mikrobiologi Umum. Edisi

keenam. Terjemahan Tedjo

Baskoro dari Allgenering

Mikrobiologie. Yogyakarta:

Universitas Gadjah Mada Press.

Stewart, G. G., dan I. Russell. 1987.

Biochemistry And Genetics Of

Carbohydrate Utilization By

Industrial Yeast Strains. Pure \&

Appl. Chem., Vol. 59, No. 11.

Wickerham, L. J., L. B. Lockwood., O. G.

Pettijohn., dan G. E. Ward. 1944.

Starch Hydrolysis And

Fermentation By The Yeast

Endomycopsis fibuliger. Journal

Of Bacteriology from American

Society of Microbiolgy.

Winarno, 1995. Enzim Pangan. Jakarta :

PT. Gramedia Pustaka Utama. 